\title{
STRATEGI PENGEMBANGAN PELUANG PASAR TANAMAN HERBAL DI KABUPATEN PASURUAN
}

\author{
Adil Abdillah \\ Universitas Mayjen Sungkono Mojokerto \\ Email: ayah.adil1181@gmail.com
}

\begin{abstract}
Research aims to know Herbal Market Opportunity Development Strategy in Pasuruan Regency with research object are herbal farmer, paguyuban farmer, herbal business and local government. The analysis used is location analysis, descriptive, marketing and SWOT. Based on the analysis and identification of field conditions, the strategy applied in the development of Pasuruan Province herbs market opportunity is Stable Growth Strategy, with strategies such as: increasing interest in the cultivation of medicinal plant commodities, Increasing training / extension related to cultivation and processing of medicinal plants, processing of medicinal plants to meet existence of market needs, expand marketing network of medical plant products and increasing partnership between farmers of medical plants in Pasuruan Regency.
\end{abstract}

Keywords: Strategy, Market Opportunities, Herbs

\begin{abstract}
ABSTRAK
Penelitian ini bertujuan untuk mengetahui strategi pengembangan peluang pasar tanaman herbal di Kabupaten Pasuruan. Dengan obyek penelitian adalah petani herbal, paguyuban petani, pelaku usaha herbal dan pemerintah daerah. Analisis yang digunakan adalah analisis lokasi, deskriptif, pemasaran dan SWOT. Berdasarkan analisis dan identifikasi kondisi di lapangan strategi yang diterapkan dalam pengembangan peluang pasar tanaman herbal Kabupaten Pasuruan adalah Stable Growth Strategy, dengan strategi antara lain: peningkatan akan minat budidaya komoditas tanaman obat, peningkatan pelatihan/penyuluhan terkait budidaya dan pengolahan produk tanaman obat, peningkatan inovasi pengolahan hasil tanaman obat untuk mencukupi pangsa pasar yang ada, perluasan jaringan pemasaran produk olahan tanaman obat dan meningkatkan kemitraan antara petani tanaman obat di Kabupaten Pasuruan.
\end{abstract}

Kata Kunci: Strategi, Peluang Pasar, Tanaman Herbal

\section{PENDAHULUAN}

Dengan adanya isu back to nature yaitu kecenderungan kembali ke alam, penggunaan bahan alam sebagai obat (biofarmaka) cenderung mengalami peningkatan namun turunnya daya beli masyarakat terhadap obatobatan modern yang relatif mahal harganya karena krisis ekonomi. Pemerintah melalui badan besar POM untuk pengembangan agroindustri tanaman obat Indonesia menetapkan 13 komoditi unggulan tanaman obat yaitu: temulawak, jati belanda, sambiloto, mengkudu, pegagan, daun ungu, sarirogo, pasak bumi, daun jinten, kencur, pala, jambu mede dan tempuyung dengan pertimbangan bahwa komoditi tersebut memiliki nilai ekonomis yang lebih tinggi. Hasil-hasil industri agromedisin asli Indonesia telah banyak dimanfaatkan oleh negara maju sebagai bahan baku obat seperti herbal medicine, food suplement, kosmetik dan parfum. Sedangkan peluang pengembangan obat tradisional Indonesia masih terbuka lebar mengingat semakin mahalnya obat sintetik tidak sebanding dengan permintaan pasar yang terus meningkat seiring dengan laju pertanaman penduduk Indonesia yang tinggi. Hal ini tentunya akan membuka peluang usaha 
tidak sebanding dengan permintaan pasar yang terus meningkat seiring dengan laju pertanaman penduduk Indonesia yang tinggi. Hal ini tentunya akan membuka peluang usaha dalam pengembangan budidaya tanaman obat secara optimal karena tanaman obat ini dapat dibudidayakan dengan teknologi yang cukup sederhana oleh petani, namun produk yang dihasilkan mempunyai nilai jual yang cukup tinggi.

Permasalahan utama yang ada saat ini adalah kurangnya pengetahuan masyarakat tentang pengembangan sumber daya hayati khususnya tanaman obat sebagai tanaman herbal untuk dioptimalkan potensinya. Disisi lain petani pembudidaya tanaman herbal pada umumnya cenderung mengejar target produksi tanpa memperhatikan kualitas dan strategi pemasarannya sehingga produksi melimpah tetapi sulit menembus peluang pasar yang lebih menjanjikan.

\section{METODE PENELITIAN}

\section{Jenis dan Pendekatan Penelitian}

Jenis penelitian ini termasuk penelitian kuantitatif yaitu penelitian yang bentuk datanya berupa angka-angka atau data kualitatif yang diangkakan dengan pendekatan explanatory research.

\section{Populasi dan Sampel Penelitian}

Penelitian ini dilakukan di Kabupaten Pasuruan dengan obyek penelitian adalah petani herbal, paguyuban petani, pelaku usaha herbal dan pemerintah daerah.

\section{Tempat dan Waktu penelitian}

Penelitian ini dilakukan di Kabupaten Pasuruan dengan mendatangi beberapa nara sumber yg berhubungan langsung dengan tanaman herbal, seperti pemerintah daerah, paguyuban, praktisi dan pengusaha tanaman herbal, pelaksanaan penyebaran kuisioner pada waktu hari efektif yaitu hari senin sampai dengan hari jumat mulai jam 07.00 sampai dengan selesai sesuai target yang telah ditentukan.

\section{Teknik Pengumpulan Data}

Metode pengumpulan data terbagi menjadi dua bagian meliputi metode pengumpulan data primer dan metode pengumpulan data sekunder. Survei primer sebagai metode pengumpulan data wawancara dengan narasumber terkait dan observasi/ pengamatan langsung pada kecamatankecamatan yang diindikasi merupakan target pengembangan tanaman Herbal di Kabupaten Pasuruan. Sedangkan untuk survei sekunder sebagai metode pengumpulan data yang dilakukan dengan cara mencari data-data yang telah tersedia pada lembaga atau instansi terkait, hasil-hasil studi yang ada, maupun kebijakan-kebijakan yang berlaku.

\section{Metode Analisis}

1. Analisis Lokasi

Penentuan lokasi dalam ruang lingkup kegiatan ekonomi, ditentukan oleh para pelaku atau faktor ekonomi yaitu, a. rumah tangga sebagai penyuplai jenis dan hasil tanaman herbal serta kegiatan konsumsi. b. perusahaan swasta yang meliputi kegiatan koleksi bahan baku (input), proses produksi, industri dan pemasaran dan c. Pemerintah dalam kewenangan penentuan kebijaksanaan perwilayahan pembangunan dan lokasi.

2. Analisis Deskriptif

Digunakan untuk mengidentifikasi potensi, permasalahan dan kendala yang dihadapi dalam penumbuhan tanaman herbal, serta kelembagaan kelompok tani tanaman herbal di Kabupaten Pasuruan. Formulasi kegiatan menggunakan beberapa alat analisis sebagai berikut:

1. Analisis kelembagaan, adanya keterkaitan peran dan fungsi beberapa lembaga masyarakat.

2. Analisis akar masalah, tahapan pelaksanaan analisis masalah secara ringkas adalah: a. mengidentifikasikan masalah utama, b. mengidentifikasikan penyebab masalah, c. mengelompokkan sebab-sebab tersebut, $d$. mengidentifikasikan tingkatan penyebab dalam bagan akar masalah (I, II, dan III), e. menentukan tujuan dan harapan.

3. Analisis tujuan, analisis tujuan adalah suatu alat untuk : a. meneliti tujuan-tujuan yang akan dicapai sebagai akibat dari pemecahan masalah-masalah yang telah disebutkan dalam analisis masalah, b. menelaah hubungan tindakan-hasil di antara 
tujuan-tujuan tersebut, c. memperlihatkan informasi ini sebagai rangkaian hubungan tindakan-hasil dalam suatu diagram.

\section{Analisis Pemasaran}

Pada analisis pemasaran mengkaji aspek bentuk dan prospek pasar tanaman herbal, proyeksi permintaan dan penawaran, pangsa pasar dan strategi pemasaran untuk mencapai pangsa pasar tersebut. Dalam analisis pemasaran ini juga dimunculkan produktivitas tanaman herbal per hektar dalam satu tahun serta nilai jual per $\mathrm{kg}$ tanaman herbal di Kabupaten Pasuruan.

4. Analisis Pengembangan (SWOT)

Menurut Sallis (2012:221) analisis SWOT adalah singkatan dari Strength (kekuatan), Weakness (kelemahan), Opportunity (kesempatan) dan Threats (ancaman), dan menginventarisasi faktorfaktor tersebut dalam wilayah perencanaan yang dipakai sebagai dasar untuk menentukan langkah-langkah perbaikan yang diperlukan dalam pengembangan selanjutnya. Faktorfaktor tersebut adalah :

1. Potensi (Strength): kekuatan apa yang dapat dikembangkan agar lebih tangguh, sehingga dapat bertahan di pasaran, yang berasal dari dalam wilayah itu sendiri.

2. Masalah (Weakness): segala faktor yang merupakan masalah atau kendala yang datang dari dalam wilayah atau obyek itu sendiri.

3. Peluang (Opportunities): kesempatan yang berasal dari luar wilayah studi. Kesempatan tersebut diberikan sebagai akibat dari pemerintah, peraturan atau kondisi ekonomi secara global.

4. Ancaman (Threats): merupakan hal yang dapat mendatangkan kerugian yang berasal dari luar wilayah atau obyek.

Dari penilaian tersebut diketahui koordinat pada sumbu $\mathrm{X}$ dan sumbu $\mathrm{Y}$, sehingga diketahui posisinya sebagai berikut :

a. Kwadran I (Growth), adalah kuadran pertumbuhan dimana pada kuadran ini terdiri dari dua ruang yaitu:

1) Ruang A dengan Rapid Growth Strategy yaitu strategi pertumbuhan aliran cepat untuk diperlihatkan pengembangan secara maksimal untuk target tertentu dan dalam waktu singkat.

2) Ruang B dengan Stable Growth Strategy yaitu strategi pertumbuhan stabil dimana pengembangan dilakukan secara bertahap dan target disesuaikan dengan kondisi.

b. Kwadran II (Stability), adalah kuadran pertumbuhan dimana pada kuadran ini terdiri dari dua ruang yaitu:

1) Ruang C dengan Agresif Maintenance Strategy dimana pengelola obyek melaksanakan pengembangan secara aktif dan agresif.

2) Ruang D dengan Selective Maintenance Strategy dimana pengelolaan obyek adalah dengan pemilihan hal-hal yang dianggap penting.

c. Kwadran III (Survival), adalah kuadran pertumbuhan dimana pada kuadran ini terdiri dari dua ruang yaitu:

1) Ruang E dengan Turn Around Strategy yaitu strategi bertahan dengan cara tambal sulam untuk operasional obyek.

2) Ruang F dengan Guirelle Strategy yaitu strategi gerilya, sambil operasional dilakukan, diadakan pembangunan atau usaha pemecahan masalah dan ancaman.

d. Kwadran IV (Diversification), adalah kuadran pertumbuhan dimana pada kuadran ini terdiri dari dua ruang yaitu:

1) Ruang G dengan Concentric Strategy yaitu strategi pengembangan obyek dilakukan secara bersamaan dalam satu naungan atau koordinator oleh satu pihak.

2) Ruang H dengan Conglomerate Strategy yaitu strategi pengembangan masingmasing kelompok dengan cara koordinasi tiap sektor itu sendiri.

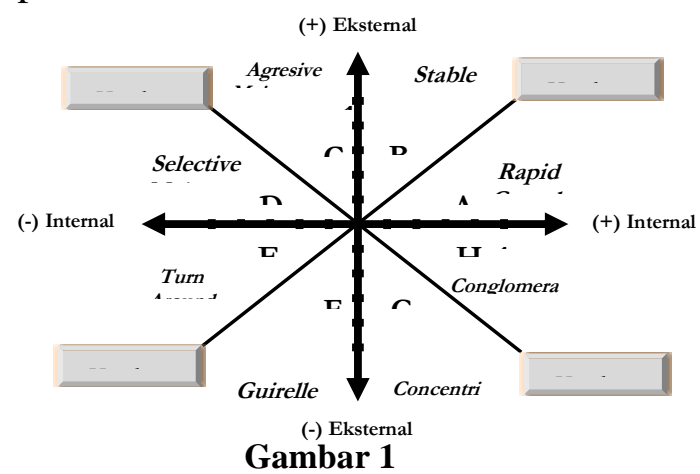

Sistem Penilaian Dalam Matrik SWOT 
ANALISIS HASIL PENELITIAN DAN PEMBAHASAN

\section{Analisis Lokasi}

Dari hasil survei dan pengumpulan data diperoleh data bahwa secara umum kondisi tanaman herbal di Kabupaten Pasuruan masih masuk dalam kategori tanaman sekunder, dalam arti para petani yang menanam tanaman herbal merupakan petani dengan produk utama non herbal, seperti tanaman pangan berupa padi, jagung, kedelai, kopi, randu, kakao atau coklat. Posisi tanaman herbal merupakan tanaman yang ditanam mendampingi tanaman utama. Komposisi jenis tanaman herbal yang ada dan dikembangkan di Kabupaten Pasuruan ada kurang lebih 14 jenis tanaman herbal.

\section{Analisis Pengolahan dan Pemasaran}

\section{Bahan Baku}

Produk olahan tanaman herbal di Kabupaten Pasuruan beraneka ragam jenisnya. Bahan baku yang dikembangkan dan dimanfaatkan untuk produk olahan tanaman herbal di Kabupaten Pasuruan diantaranya yang utama adalah kunyit, temulawak, jahe merah, sambiloto, kunci sirih, jati londo dan lain-lain. Berdasarkan hasil survei sekunder yang telah dilakukan, jenis olahan tanaman herbal yang dikembangkan di Kabupaten Pasuruan antara lain: jamu instan/ herbal, minuman herbal, herbal kering, produk olahan toga, serta tanobat. Data UKM dan jenis usaha produk olahan tanaman obat yang dikembangkan di Kabupaten Pasuruan, sebagai berikut :

\section{Tabel 1}

Data UKM Pembuat Jamu Instan Kabupaten Pasuruan

\begin{tabular}{|c|l|l|l|}
\hline No & $\begin{array}{l}\text { Nama } \\
\text { Perusahaan/Pemilik }\end{array}$ & \multicolumn{1}{|c|}{ Jenis Usaha } & \multicolumn{1}{|c|}{ Alamat } \\
\hline 1 & $\begin{array}{l}\text { "Kasiman Jaya"/ Hj. } \\
\text { Kariyani }\end{array}$ & $\begin{array}{l}\text { Jamu instan, } \\
\text { minuman herbal }\end{array}$ & $\begin{array}{l}\text { Ds. Kesiman } \\
\text { Sukoreno } \\
\text { Kecamatan } \\
\text { Prigen }\end{array}$ \\
\hline 2 & Sukarni & Jamu instan & $\begin{array}{l}\text { Jl. Palem Indah } \\
\text { Kecamatan } \\
\text { Prigen }\end{array}$ \\
\hline 3 & Anik Purwaningsih & Herbal kering & $\begin{array}{l}\text { Jl. Macanan 12 } \\
\text { Kecamatan } \\
\text { Pandaan }\end{array}$ \\
\hline 4 & Sulastri & Jamu instan & $\begin{array}{l}\text { Jatianom 01/VI } \\
\text { Karangjati }\end{array}$ \\
\hline
\end{tabular}

\begin{tabular}{|c|l|l|l|}
\hline No & \multicolumn{1}{|c|}{$\begin{array}{c}\text { Nama } \\
\text { Perusahaan/Pemilik }\end{array}$} & \multicolumn{1}{|c|}{ Jenis Usaha } & \multicolumn{1}{c|}{ Alamat } \\
\hline 5 & Didik Eko Nugroho & $\begin{array}{l}\text { Produk olahan } \\
\text { toga } \\
\text { Pandaan }\end{array}$ & $\begin{array}{l}\text { Sumberdawesari- } \\
\text { Grati }\end{array}$ \\
\hline 6 & $\begin{array}{l}\text { "Okky Jaya" } \\
\text { Sayuni }\end{array}$ & $\begin{array}{l}\text { Jamu instan, } \\
\text { temulawak, kunir, } \\
\text { jahe, jati londo }\end{array}$ & $\begin{array}{l}\text { Jl. Sidosari No. } \\
\text { 35 RT 2/III } \\
\text { Kecamatan } \\
\text { Purwodadi }\end{array}$ \\
\hline 7 & Ma'arif & $\begin{array}{l}\text { Tanobat } \\
\text { Ds. Ngadimulyo } \\
\text { 01/VI } \\
\text { Kecamatan } \\
\text { Sukorejo }\end{array}$ \\
\hline 8 & Siti Khotijah & $\begin{array}{l}\text { Minuman instan, } \\
\text { herbal tanaman } \\
\text { obat }\end{array}$ & $\begin{array}{l}\text { Ds. Ngadimulyo } \\
\text { Kecamatan } \\
\text { Sukorejo }\end{array}$ \\
\hline 9 & Wulan & $\begin{array}{l}\text { Jamu instan } \\
\text { herbal }\end{array}$ & $\begin{array}{l}\text { Ds. Pacarkeling } \\
\text { Kecamatan } \\
\text { Kejayan }\end{array}$ \\
\hline
\end{tabular}

Sumber: Dinas Koperasi UKM Kabupaten Pasuruan

Para kelompok tani biasanya menyetorkan hasil panen mereka ke pemilik usaha olahan tanaman herbal yang ada di Kabupaten Pasuruan. Semua jenis tanaman obat di Kabupaten Pasuruan memiliki masa tanam hingga panen selama 1 hingga 1,5 tahun. Selain bahan baku sudah dapat terpenuhi dari dalam Kabupaten Pasuruan sendiri, para pelaku usaha olahan tanaman herbal (seperti UKM Kasiman Jaya di Kecamatan Prigen) juga mengambil bahan baku dari luar wilayah Kabupaten Pasuruan khususnya untuk produk olahan yang bukan komoditas yang ada di Kabupaten Pasuruan, misalnya pasak bumi (dari Palangkaraya), sarang semut (dari Malang). Berdasarkan hasil wawancara kebeberapa pemilik usaha produk tanaman obat diketahui bahwa asumsi bahan baku yang digunakan untuk proses produksi olahan tanaman obat membutuhkan $10 \mathrm{~kg}$ tanaman obat menghasilkan 40 botol jamu setelah diproses. Bahan baku tanaman obat yang dibutuhkan setiap harinya dalam proses pengolahan produk herbal sekitar 10 hingga 25 kg per hari.

2. Modal

Modal yang digunakan dalam proses produksi olahan tanaman herbal sekitar Rp. 500.000-1.000.000 tergantung besar kecilnya usaha produksi masing-masing perusahaan tanaman herbal. Selama ini modal yang digunakan untuk proses produksi masih terbatas dan modal pribadi. Salah satu permasalahan modal inilah yang sampai saat 
ini dikeluhkan para pelaku industri kecil/rumahan produk olahan tanaman herbal dalam pengembangan usahanya.

\section{Tenaga Kerja}

Kebutuhan tenaga kerja kerja mayoritas berasal dari wilayah sekitar usaha produk olahan tanaman herbal dan biasanya sudah tergabung dengan kelompok tani tanaman obat kecamatan masing-masing. Tenaga kerja untuk pengelolaan tanaman obat dari tahap penanaman hingga panen membutuhkan sekitar 4 tenaga kerja per hektarnya, sedangkan tenaga kerja yang dibutuhkan untuk proses pengolahan produk hasil tanaman obat sekitar 2 hingga 6 tenaga kerja tergantung besar kecilnya perusahaan tanaman herbal yang dimiliki. SDM tenaga kerja mayoritas lulusan SD hingga SLTP/sederajat sehingga pengetahuan dan keterampilan petani herbal terbatas.

4. Proses Pengolahan Produk Olahan

\section{Tanaman Herbal}

Proses dan teknologi pengolahan produk olahan tanaman herbal di Kabupaten Pasuruan sampai saat ini masih bersifat sederhana berupa, parutan (manual dan mesin), pemeras/saringan, alat pengering (oven), alat pres (bungkus), alat memasak, ember (penyimpan serbuk sementara sebelum dikemas).

5. Pemasaran Produk Olahan Tanaman Herbal

Pemasaran produk olahan tanaman herbal selain dijual dipasarkan di Kabupaten Pasuruan sendiri, juga sudah dipasarkan di luar daerah seperti Surabaya, Yogyakarta, Banjarmasin, Mataram, serta Bali. Pendistribusian produk herbal ini biasanya ada pengepul/distributor yang mengambil langsung di perusahaan UKM herbal di Kabupaten Pasuruan kemudian dipasarkan sendiri di luar daerah Kabupaten Pasuruan. Sehingga untuk meningkatkan pemasaran dan promosi produk olahan tanaman herbal, selama ini para pelaku UKM produk herbal mengikuti pameran-pameran produk yang diselenggarakan oleh dinas-dinas di Kabupaten Pasuruan sendiri atau luar daerah.

\section{Analisis Kelembagaan}

Penetapan Kelembagaan Kelompok Tani

Berdasarkan surat keputusan Bupati Pasuruan Nomor: 521/437/HK/424.013/2011 Tentang Penetapan Kelembagaan PetaniNelayan dan Wilayah Binaan Penyuluh Pertanian Kabupaten Pasuruan, kelompok tani terbagi dari : 1 . Kelompok tani : 1.538 Klp (Kategori Pemula: 774 klp; b. Kategori Lanjut: 671 klp; c. Kategori Madya: 86 Klp; d. Kategori Utama: 5 Klp). 2. Kelompok PetaniNelayan Kecil: 383 klp; 3. Gabungan Kelompok Tani (Gapoktan): 269 klp; 4. Koperasi Tani : 17 unit; 5. Asosiasi Petani : 5 unit.

Kelembagaan Masyarakat Pangan : 1 . Kelompok Lumbung Pangan: $19 \mathrm{klp} ; 2$. Kelompok Tunda Jual: 2 klp; 3. Kelompok Cadangan Pangan: 1 klp; 4. Kelompok Olahan Pangan: 54 Klp. Kelompok petani herbal selama ini bergabung dengan kelembagaan Gapoktan (Gabungan Kelompok Tani) di Kabupaten Pasuruan. Kelompok tani herbal yang ada di Kabupaten Pasuruan antara lain (hasil wawancara/survey lapangan):

\section{Gapoktan "Karsa Tani" Kecamatan Purwosari}

Jumlah petani herbal di Kecamatan Purwosari sebanyak 40 orang dengan luas lahan yang dikelola oleh kelompok tani di Kecamatan Purwosari sekitar 380 Ha. Lahan yang dipergunakan adalah milik perhutani, dengan biaya sewa 200 ribu / tahun. Lahan tersebut ditanami $10 \mathrm{Ha}$ untuk jenis jahe, $5 \mathrm{Ha}$ untuk kunyit. Masa panen jenis tanaman tersebut sekitar 1-1,5 tahun. Tanaman jahe 1 Ha menghasilkan 1,2 ton dengan harga jahe 3 $7 \mathrm{ribu} / \mathrm{kg}$. Sedangkan hasil kunyit dari $1 \mathrm{M}^{2}$ menghasilkan $3 \mathrm{~kg}$, dengan luasan lahan $5 \mathrm{Ha}$ maka dapat menghasilkan 150 ton kunyit. Distribusi penjualan jahe dan kunyit ke UKM pembuat jamu herbal 'Kasiman Jaya'di Kecamatan Prigen serta ada pengepul yang datang dari Surabaya dan pedagang kecil dari sekitar Pasuruan. Permasalahan yang dialami oleh kelompok tani tanaman obat di Kecamatan Purwosari adalah 1) permodalan untuk membuka lahan baru, 2) kemudahan untuk akses pasar hasil panen, 3) SDM masih 
terbatas, 4) pemasaran hasil tanaman herbal terbatas, 5) hasil panen berdasarkan uji kelayakan masih jauh kurang memenuhi standar industri obat dan jamu, 6) dibutuhkan kerjasama dengan penanam modal, 7) kondisi cuaca yang sangat mempengaruhi hasil panen.

$\begin{array}{lll}\text { Gapoktan "Sumbertani" } & \text { Kecamatan } \\ \text { Purwodadi } & \end{array}$

Lokasi di Desa Gerbo di Kecamatan Purwodadi. Jumlah petani herbal sebanyak 75 orang. Komoditi yang dikembangkan jahe merah dan kunyit dengan luas lahan yang ditanami jahe merah $12 \mathrm{Ha}$ dan kunyit $3 \mathrm{Ha}$. Lahan yang dipergunakan adalah milik perhutani. Masa panen jenis tanaman ini sekitar setahun sekali. Tanaman jahe $1 \mathrm{Ha}$ menghasilkan 1-1,2 ton dengan harga jahe $3-6$ ribu $/ \mathrm{kg}$. Untuk kunyit harga Rp 3.000/kg. Asumsi hasil kunyit dari 1M2 menghasilkan 3 $\mathrm{kg}$, dengan luasan lahan $3 \mathrm{Ha}$ maka dapat menghasilkan 90 ton kunyit.Untuk pemasaran hasil kunyit, ada pengepul yang datang dari sekitaran Kabupaten Pasuruan. Permasalahan yang dialami oleh kelompok tani tanaman obat di Kecamatan Purwosari sama dengan permasalahan kelompok tani di kecamatan Purwosari.

\section{Gapoktan "Tani Terang" Kecamatan Pasrepan}

Lokasi di Desa Mangguandengan jumlah anggotanya sekitar 20 orang dengan komoditi tanaman obat berupa jahe, kunir, kencur, temulawak, temu ireng dan laos. Lahan yang digunakan untuk menanam tanaman obat ini merupakan lahan pribadi dan biasanya memanfaatkan didepan dan dipekarangan rumah dengan ukuran beragam mulai $20 \mathrm{M}^{2}$ hingga $100 \mathrm{M}^{2}$. Untuk ukuran $20 \mathrm{M}^{2}$ menghasilkan 5 pikulan panen. Komoditi yang berpotensi adalah kencur dijual dalam bentuk keranjang atau pikulan dengan kisaran harga Rp 125 ribu untuk ukuran 20-25kg, Jahe seharga 15.000/kg dan dipanen setiap 3 bulan sekali, Kencur seharga $1.000 / \mathrm{kg}$ dan dipanen setiap 3 bulan sekali, Temulawak seharga $10.000 / \mathrm{kg}$ untuk ukuran 1 keranjang atau pikulan dan dipanen setiap 3 bulan sekali, Laos seharga $1.000 / \mathrm{kg}$ dan dipanen setiap 3 bulan sekali. Untuk pemasaran masih dipasarkan didaerah lokal yaitu dipasar pasrepan. Inovasi produk olahan hasil tanaman herbal masih belum ada. Permasalahan yang dialami oleh kelompok tani tanaman obat di Kecamatan Pasrepan adalah : 1. Para petani masih berjalan sendiri tanpa adanya koordinasi dalam usaha tanaman herbal; 2. Air sulit didapat, sumber mata air jauh dan airnya keruh; 3. Belum ada CSR dan pihak ketiga untuk memberikan inovasi dan pelatihan; 4. Kurangnya SDM untuk mengelola menjadi tanaman obat; 5. Dibutuhkan informasi harga pasar produk tanaman herbal.

\section{Peran dan Fungsi Kelembagaan Tanaman Herbal di Kabupaten Pasuruan}

Peran dan fungsi beberapa lembaga masyarakat dalam pengembangan tanaman herbal di Kabupaten Pasuruan yang menunjang strategi pengembangan potensi dan peluang pasar tanaman herbal. Terdapat lima (5) lembaga yang terkait dengan masyarakat sebagai berikut :

1. Pemerintah Daerah/Instansi terkait; Dinas Perkebunan dan Kehutanan, Dinas Ketahanan Pangan dan Penyuluhan Pertanian, Dinas Koperasi dan UKM, Dinas Perindustrian dan Perdagangan, serta Dinas Kesehatan yang memiliki peranan yang penting dalam perkembangan potensi dan peluang pasar tanaman herbal. Instansi terkait memiliki fungsi antara lain memberikan pengawasan/monitoring, pelatihan, penyuluhan serta informasi teknologi pertanian pada petani tanaman obat dalam meningatkan produktivitas dan inovasi produk tanaman obat.

2. Pengepul; memiliki fungsi mengumpulkan hasil panen tanaman obat dan mendistribusikan ke pasar (dijual dalam bentuk mentah tanpa diolah) atau UKM yang akan mengolah hasil tanaman obat menjadi suatu produk herbal.

3. Industri Herbal (Usaha Kecil dan Menengah); Industri rumahan produk tanaman herbal sangat tergantung dengan petani tanaman obat dalam memenuhi bahan baku. 
4. Kelompok Petani Herbal; Keberadaan kelompok petani tanaman obat di Kabupaten Pasuruan sangat erat dengan pelaku usaha kecil dan menengah (UKM).

5. Pembeli Swasta; memiliki hubungan langsung dengan pengepul/agen distribusi, adanya kerjasama antara pengepul/agen distribusi dengan pembeli swasta secara tidak langsung meningkatkan kondisi perekonomian masyarakat yang bermata pencaharian sebagai pelaku usaha produk olahan tanaman obat. Pembeli swasta ini berasal dari Surabaya, Mataram, Banjarmasin, Bali serta Yogyakarta.

\section{Analisis Akar Masalah Dan Tujuan}

Permasalahan dalam pengembangan tanaman herbal adalah potensi dan peluang tanaman herbal di Kabupaten Pasuruan masih rendah. Hal ini disebabkan oleh beberapa faktor utama yaitu :

1. Kualitas standart mutu tanaman obat masih sangat rendah dipengaruhi oleh: faktor ketersediaan air, kurangnya pelatihan dan pembinaan ke petani obat, keterbatasan modal dan peralatan, serta SDM rendah.

2. Peluang pasar produk olahan herbal masih rendah dipengaruhi oleh : faktor informasi pasar yang tidak pasti, belum adanya ijin usaha (sertifikasi halal).

\section{Analisis SWOT}

Analisis SWOT adalah analisis untuk mengetahui faktor-faktor yang mempengaruhi suatu wilayah perencanaan, yaitu untuk melihat Strength (kekuatan), Weakness (kelemahan), Opportunity (kesempatan) dan Threats (ancaman), dan menginventarisasi faktor-faktor dan langkah-langkah perbaikan. Berdasarkan hasil analisis SWOT disajikan pada tabel berikut ini :

Tabel 2

Matriks Analisis Internal (Strength dan Weakness)

\begin{tabular}{|l|l|}
\hline ANALISIS INTERNAL \\
\hline Kekuatan (Strength) & Kelemahan (Weakness) \\
\hline Wilayah Kabupaten Pasuruan & $\begin{array}{l}\text { Pengembangan akan minat } \\
\text { memiliki potensi pertanian dan }\end{array}$ \\
budidaya tanaman obat perlu \\
perkebunan yang cukup besar & ditingkatkan karena secara umum \\
sehingga mampu menghasilkan & kondisi tanaman herbal di \\
produk-produk pertanian yang & Kabupaten Pasuruan masih \\
berkualitas, hal ini mendukung & masuk dalam kategori tanaman \\
dalam pengembangan tanaman & sekunder. \\
obat baik untuk luasan & Keterbatasan modal yang \\
pengembangan lahan maupun & dimiliki para pelaku tanaman \\
\hline
\end{tabular}

\begin{tabular}{|c|c|}
\hline $\begin{array}{l}\text { fasilitas penunjangnya. } \\
\text { Terdapat UKM dan kelompok } \\
\text { pembudidaya tanaman obat yang } \\
\text { menyebar merata di Kabupaten } \\
\text { Pasuruan } \\
\text { Kemampuan dan inovasi produk } \\
\text { olahan tanaman obat yang } \\
\text { bervariasi di Kabupaten Pasuruan } \\
\text { sehingga mampu bersaing di } \\
\text { pasaran. } \\
\text { Jangkauan aksesbilitas dan lokasi } \\
\text { budidaya tanaman obat hingga } \\
\text { pemasaran yang memadai. }\end{array}$ & $\begin{array}{l}\text { obat (petani dan UKM). } \\
\text { Kualitas mutu tanaman obat } \\
\text { masih kurang memenuhi standart } \\
\text { yang telah ditetapkan oleh } \\
\text { perusahaan obat yang skalanya } \\
\text { besar. } \\
\text { Peralatan dan teknologi olahan } \\
\text { masih terbatas dan tradisional } \\
\text { SDM tenaga kerja (petani/pelaku } \\
\text { industri kecil herbal)masih } \\
\text { rendah sehingga pengetahuan } \\
\text { dan keterampilan petani herbal } \\
\text { terbatas. } \\
\text { Pelatihan dan pembinaan oleh } \\
\text { dinas terkait belum diterapkan } \\
\text { secara maksimaloleh petani dan } \\
\text { pelaku UKM olahan tanaman } \\
\text { obat } \\
\text { Kurangnya sarana informasi } \\
\text { pasar tanaman obat } \\
\text { Kemitraan antara petani/UKM } \\
\text { dengan investor/swasta/CSR, } \\
\text { perusahaan obat, pemerintah } \\
\text { terkaitdalam hal pengolahan hasil } \\
\text { tanaman obat, modal dan } \\
\text { pemasaran produk yang masih } \\
\text { kurang. }\end{array}$ \\
\hline
\end{tabular}

Sumber : Hasil Analisis, Tahun 2018

Tabel Matriks Analisis Eksternal (Opportunities dan Threats)

\begin{tabular}{|c|c|}
\hline Peluang (Opportunities) & Ancaman (Threats) \\
\hline $\begin{array}{l}\text { Permintaan akan produk olahan } \\
\text { tanaman herbal yang tinggi di } \\
\text { Kabupaten Pasuruan } \\
\text { Adanya kerja sama para pelaku } \\
\text { tanaman obat (kelompok petani dan } \\
\text { UKM) dengan para swasta/CSR } \\
\text { sehingga mampu membantu dalam } \\
\text { peningkatan budidaya tanaman obat } \\
\text { di Kabupaten Pasuruan } \\
\text { Seringnya kegiatan promosi produk } \\
\text { olahan tanaman herbal dengan cara } \\
\text { pameran-pameran produk yang } \\
\text { diselenggarakan oleh dinas terkait } \\
\text { di Kabupaten Pasuruan sendiri atau } \\
\text { luar daerah. }\end{array}$ & $\begin{array}{l}\text { Belum adanya kebijakan } \\
\text { pengembangan lokasi lahan- } \\
\text { lahan untuk fungsi khusus } \\
\text { pertanian tanaman obat } \\
\text { (herbal)pada Rencana Tata } \\
\text { Ruang Wilayah Kabupaten } \\
\text { Pasuruan } \\
\text { Pada saat musim kemarau, } \\
\text { air susah didapat sehingga } \\
\text { mempengaruhi proses } \\
\text { pengairan tanaman herbal. } \\
\text { Belum adanya kebijakan } \\
\text { kredit bagi } \\
\text { petani/UKMtanaman obat di } \\
\text { Kabupaten Pasuruan }\end{array}$ \\
\hline
\end{tabular}

Sumber : Hasil Analisis, Tahun 2018

Berikut ini merupakan hasil analisis dengan metode SWOT melalui proses telaah IFAS (Internal Strategic Factors Analysis Summary) dan EFAS (Eksternal Strategic Factors Analysis Summary) untuk kemudian diketahui posisi kedudukannya dalam kuadran SWOT. Dari pembobotan diatas, maka dapat diketahui nilai X dan Y sebagai berikut :

Sumbu $\mathrm{X}=$ potensi - masalah $=1,88+$ $(-1,74)=0,14$

Sumbu Y = peluang + ancaman $=2,308+$ $(-1,346)=0,962$

Pembagian ruang dalam analisis SWOT dengan penilaian terhadap faktor internal 
(IFAS) dan faktor eksternal (EFAS) tersebut dapat dilihat pada gambar berikut ini :

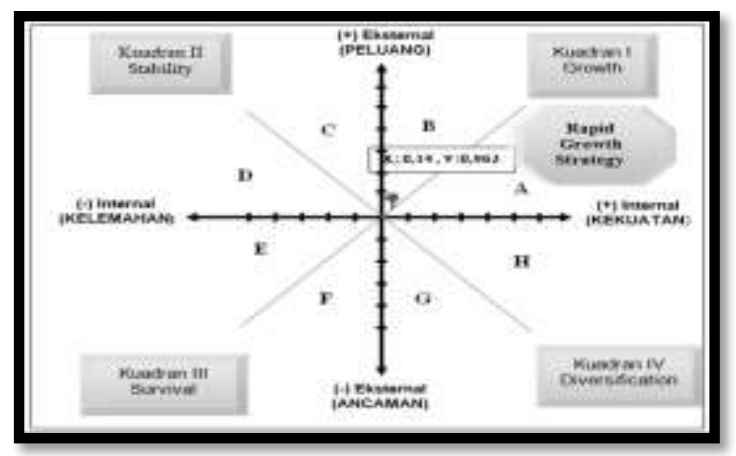

Gambar Matrik SWOT Strategi

Pengembangan Potensi dan Peluang Pasar Tanaman Herbal Kabupaten Pasuruan

Berdasarkan kondisi di lapangan dan hasil analisis yang ada maka Stable Growth Strategy diterapkan dengan:

1. Pengembangan minat budidaya komoditas tanaman obat perlu ditingkatkan pada sektor pertanian.

2. Peningkatan pelatihan/penyuluhan terkait budidaya dan pengolahan produk tanaman obat dilakukan secara langsung dan berkelanjutan dengan transfer teknologi tepat guna sehingga dapat dipahami dan mampu diimplementasikan oleh kelompok petani tanaman obat serta pelaku UKM di Kabupaten Pasuruan.

3. Peningkatan sarana dan prasarana (peralatan) penunjang pertanian guna meningkatkan hasil produksi.

4. Peningkatan inovasi pengolahan hasil tanaman obat untuk mencukupi pangsa pasar yang ada.

5. Perluasan jaringan pemasaran produk olahan tanaman obat misalnya dengan cara promosi/pameran produk pada tingkat regional-nasional untuk memperluas pangsa pasar, serta pembentukan kemitraan antara pelaku tanaman obat (petani dan UKM) dengan perusahaan produk tanaman obat yang lebih besar skalanya untuk memperluas jaringan distribusi.

6. Meningkatkan kemitraan antara petani tanaman obat di Kabupaten Pasuruan dengan pemerintah, investor/swasta/CSR dan distributor terkait dalam penyediaan modal, peralatan pengelolaan tanaman obat, pengolahan hasil tanaman obat dan pemasaran produk.

\section{KESIMPULAN}

Simpulan yang didapatkan dari analisis sebelumnya terkait dengan penyusunan strategi pengembangan peluang pasar tanaman herbal kabupaten pasuruan adalah :

Faktor-faktor yang berpengaruh pada pengembangan tanaman herbal di Kabupaten Pasuruan, diantaranya : permodalan untuk membuka lahan baru, kemudahan untuk akses pasar hasil panen, SDM masih terbatas, pemasaran hasil tanaman herbal terbatas, hasil panen berdasarkan uji kelayakan masih jauh kurang memenuhi standar industri obat dan jamu, dibutuhkan kerjasama dengan penanam modal, kondisi cuaca yang sangat mempengaruhi hasil panen, air sulit didapat, sumber mata air jauh dan airnya keruh, belum ada CSR dan pihak ketiga untuk memberikan inovasi dan pelatihan.

Identifikasi peluang pasar tanaman herbal termasuk tata niaga dan peluang industri (UKM) tanaman herbal, di Kabupaten Pasuruan. Berdasarkan analisis dan identifikasi kondisi di lapangan strategi yang diterapkan dalam pengembangan potensi dan peluang pasar tanaman herbal Kabupaten Pasuruan adalah Stable Growth Strategy, yang diterapkan dengan: a. Peningkatan minat masyarakat dalam menanam tanaman herbal atau obat agar bahan baku tetap tersedia; b. Peningkatan pelatihan/penyuluhan terkait budidaya dan pengolahan produk tanaman obat dilakukan secara langsung dan berkelanjutan dengan transfer teknologi tepat guna; c. Peningkatan inovasi pengolahan hasil tanaman obat untuk mencukupi pasaran dengan cara pengadaan pelatihan serta pengoptimalan penyuluhan pengembangan olahan tanaman obat, peningkatan penguasaan teknologi modern, serta peningkatan kualitas produk hasil panen; d. Perluasan jaringan pemasaran produk olahan tanaman obat misalnya dengan cara promosi/pameran produk pada tingkat regional-nasional untuk memperluas pangsa pasar. 


\section{DAFTAR PUSTAKA}

Dalimartha, Setiawan. 2002. Atlas Tumbuhan Obat Indonesia. Jakarta: Trubus Agriwidya.

http://www.bbpplembang.info/index.php/en/ar sip/artikel-pertanian/585-potensi-tanamanobat-indonesia. Diakses 12 Desember 2019 pukul 23:43 WIB.

http://kumpulanbungamawrku.blogspot.com.

Diakses 12 Desember 2019 pukul 22:23 WIB.

Kertajaya, Hermawan. 2009. New Wave Marketing. Jakarta: Gramedia Pustaka Utama.

Kotler, Philip dan Kevin Lane Keller. 2009. Manajemen Pemasaran. Jakarta: Gramedia.

Sallis, Edward. 2012. Total Quality Management In Education (Manajemen Mutu Pendidikan). Yogyakarta: IRCiSoD.

Wibisono. 2006. Manajemen Kinerja, Konsep, Desain dan Teknik Perusahaan. Jakarta: Pustaka Setia. 